\title{
Biochemical Resistance Traits of Bitter Gourd against Fruit Fly Bactrocera cucurbitae (Coquillett) Infestation
}

\author{
Paras Nath ${ }^{1}$, A. K. Panday ${ }^{2}$, Akhilesh Kumar ${ }^{2}$, A. B. Rai ${ }^{3} \&$ Hemalatha Palanivel $^{1}$ \\ ${ }^{1}$ College of Agriculture, Fisheries and Forestry, Fiji National University, Koronivia, Fiji \\ ${ }^{2}$ Department of Entomology and Agricultural Zoology, BHU, Varanasi, India \\ ${ }^{3}$ Indian Institute of Vegetable Research, Varanasi, India \\ Correspondence: Hemalatha Palanivel, Department of Genetics and Plant Breeding, College of Agriculture, \\ Fisheries and Forestry, Fiji National University, Koronivia, Fiji. Tel: 679-347-9200. Ext. 5077. E-mail: \\ hemalatha.palanivel@fnu.ac.fj
}

Received: October 9, 2016

Accepted: December 9, $2016 \quad$ Online Published: January 15, 2017

doi:10.5539/jas.v9n2p217

URL: http://dx.doi.org/10.5539/jas.v9n2p217

\begin{abstract}
Host plant resistance is a key factor for management of the melon fruit fly, Bactrocera cucurbitae (Coquillett), due to difficulties associated with its chemical and biological control. Various biochemical traits including total sugars, reducing sugars, non-reducing sugars, silica, protein content, ash content, other elements and phenols, and moisture content of fruit were studied on 74 varieties/genotypes of bitter gourd (Momordica charantia L.), in relation to resistance against B. cucurbitae under field conditions. Seventy-four genotypes of bitter gourd were screened against fruit fly infestation. The correlation coefficients revealed that the larval density and bitter gourd fruit damage $(\%)$ had significant positive relationship $(r=0.99)$. The moisture content had significant positive effect on the fruit damage $(r=0.75)$ and number of larvae per fruit $(0.80)$. Significant differences were found in tested varieties/genotypes for fruit infestation and larval density per fruit. The nitrogen, phosphorous, potassium and protein content $(\mathrm{r}=-0.87,-0.90)$ showed significant negative correlation with fruit fly infestation. The non-reducing, reducing, total sugars, total phenols, silica and ash content had significant impact on the fruit damage and showed significant negative correlation with fruit fly infestation. The ascorbic acid also had significant impact on the fruit damage and showed significant negative correlation with fruit fly infestation $(r=-0.79)$, the chlorophyll ' $a$ ', ' $b$ ' and total chlorophyll content had non-significant negative effect on the fruit damage and number of larvae per fruit.
\end{abstract}

Keywords: biochemical traits, bitter gourd, fruit fly resistance, screening

\section{Introduction}

Vegetables are one of the most important components of Indian horticulture. In recent past tremendous progress has been made and as a result, India has emerged as second largest producer of vegetables next after China (Panday et al., 2009). Among the various vegetable crops, cucurbitaceous vegetables that include bitter gourd, cucumber, melons, pumpkins and various types of gourds are of major importance in the Indian subcontinent and include the largest number of summer and rainy season vegetables. Bitter gourd (Momordica charantia) is one of the most popular vegetables in Southeast Asia. Bitter gourd (Momordica charantia L., Cucurbitacae), commonly known as balsam pear, or Karela, was cultivated throughout the world, especially in the tropical areas (ElBatran et al., 2006). In terms of nutritive value, bitter gourd ranks first among cucurbits, being rich in iron, phosphorus and ascorbic acid (Awasthi \& Jaiswal, 1986). A substance with clinical properties of insulin has been isolated from bitter gourd fruits and hence is recommended for consumption to diabetic patients (Baldwa et al., 1977; Aslam \& Stockley, 1979; Kedar \& Chakraborti, 1982). Bitter gourd has good export potential and its share in export of green vegetable is to the extent of 20 per cent (Anonymous, 1992).

Insect pests are a major constraint for increasing the production and productivity of this crop. Bitter gourds are attacked by several insect pests, among them the fruit fly is one of the most destructive insect-pests (Panday et al., 2008). Melon fruit flies (Diptera: Tephritidae: Dacinae) are economically important pests of the cucurbits and are geographically distributed throughout the tropics and subtropics of the world (Chinajariyawong et al., 2003), especially in most countries of South East Asia (Allwood et al., 1999). The extent of losses varies between 30 
and $100 \%$ depending on the cucurbit species and the season. (Pareek \& Kavadia, 1995; Kapoor, 1993; Panday et al., 2009). The melon fly has been observed on 81 host plants, with watermelon being a highly-preferred host, and has been a major limiting factor in obtaining good-quality fruits and high yield (Nath \& Bhushan, 2006).

As a result of the recent efforts, made by the Environmental Protection Agency, to reduce the use of harmful insecticides, especially, organophosphates, organochlorines, some carbamates and pyrethroids, in the agricultural crops, the trend has now shifted towards an integrated pest management (IPM) for the control of tephritid fruit flies (Roger et al., 2010). Integrated pest management (IPM), includes, a combination of chemical, biological and cultural control tactics (Sarfaraz et al., 2002), with insecticides still to continue as an important components of such strategies. But, the larvae of melon fruit flies, like, other fruit flies often pupate either in the soil, inside the fruits or under the fruits, thereby avoiding the exposure to or contact with insecticides, when surface application is practiced. Similarly, the maggots damage the fruits internally. Therefore, it is imperative to explore alternative methods of control of this pest. Hence, the development of varieties resistant to melon fruit fly is an important component for an integrated pest management of this pest (Panda \& Khush, 1995).

The development and then the cultivation of fruit fly resistant bitter gourd cultivars has been limited, because of the lack of adequate information on the genetic variability and sources of resistance in the available bitter gourd genotypes and influence of these sources on the pest multiplication (Dhillon et al., 2005). Therefore, it becomes imperative to identify sources of resistance in bitter gourd and get knowledge of their influence on oviposition preference, larval performance and pest multiplication for devising sustainable pest management strategies

The identification of biochemical factors governing resistance is helpful in the development of rapid screening technique. The mechanism of resistance may be antixenosis, antibiosis and tolerance. The bitter gourd varieties having such inhibitory mechanism of resistance to melon fruit fly can be used in transferring the resistance in to the commercially acceptable varieties. The chemical defenses in plants against predators and parasites are known since antiquity. Biochemical studies can only follow a successful discovery of sources of resistance. It is well established that chemical stimuli play a major role in host plant selection by insect for both feeding and oviposition (Maxwell \& Jennings, 1980). Antixenosis refers to the potential plant characteristics/traits, either allelochemical or morphological, that impart or alter insect behaviour towards the host (Haldhar et al., 2013). Resistance in a given plant species, as expressed in the field, is a complex phenomenon and there is generally no single chemical to condition it. The extent of losses varies between 30 and $100 \%$, depending on the cucurbit species and the season. As the maggots damage the fruits internally, it is difficult to control this pest with insecticides. Hence, development of bitter gourd varieties/genotypes resistant to the fruit fly is an important component of integrated pest management (Panda \& Khush, 1995), but it has been limited in India owing to inadequate information on the sources of plant traits associated with resistance to pest infestations. The present study was designed to identify various morphological biochemical (allelochemical) fruit traits of bitter gourd varieties/genotypes associated with resistance against the fruit fly in terms of fruit infestation and larval density under field conditions.

\section{Materials and Methods}

\subsection{Preliminary Screening}

Little is known about the biochemical basis of resistance in bitter gourd against the infestation of fruit fly. If the factors responsible for imparting resistance in fruits of bitter gourd are known they can be used as markers for selecting resistant plant materials within a short period of time. To study the biochemical basis of resistance to the melon fruit fly, estimation of various bio-chemicals were done for this study, sixteen genotypes comprising of two highly resistant, three resistant, three moderately resistant, two susceptible and two highly susceptible were selected from the preliminary screening of 74 bitter gourd genotypes. The seeds were sown in summer season of the year 2009 and 2010 at the vegetable research Farm of Indian Institute of Vegetable Research, Varanasi $\left(25.10^{\circ} \mathrm{N}\right.$ and $\left.82.52^{\circ} \mathrm{E}\right)$ with 3 replicates (blocks) for each variety/genotype in a randomized block design. The pits were dig of $30 \mathrm{~cm} \times 30 \mathrm{~cm} \times 30 \mathrm{~cm}$ size at $2 \times 1.5 \mathrm{~m}$ spacing and form basins and Installed drip system with main and sub-main pipes and place the inline lateral tubes at an interval of $1.5 \mathrm{~m}$. Recommended agronomic practices were followed for raising the healthy crop. The marketable fruits were picked at weekly intervals for observations of fruit fly infestation and number of larvae per fruit. The infested and healthy fruits were counted to know the per cent fruit infestation. The infested fruits were cut and open to count the number of larvae per fruit. All the screened genotypes were grouped in to different categories on the basis of per cent fruit infestation and number of larvae per fruit (Nath, 1966). The pericarp was air dried for five days and milled with an aid of electrical grinder. The ethanol extract of each sample was prepared by soaking $150 \mathrm{~g}$ of dried powder in one litre of ethanol for 24 hours as incubation period. The extract was filtered with Whatman's filter paper 
number 42. The observations on biochemical traits were recorded on five randomly selected marketable size fruits in three replications. The moisture content was calculated by the following formula,

$$
\text { Per cent moisture content }=\frac{\text { Fresh weight of sample }- \text { Dry weight of sample }}{\text { Fresh weight of samples }} \times 100
$$

The different biochemical constituents were estimated by different standard methods, Chlorophyll ' $a$ ', ' $b$ ' and total chlorophyll were estimated by the method suggested by Mahlberg and Venketeswaran (1966), ascorbic acid was determined by 2, 6 dichlorophenol indophenol titration method (AOAC, 1960), total nitrogen was determined by Microkjeldahl's method (AOAC, 1985). The nitrogen percentage was multiplied by 6.25 to get total protein percentage. Phosphorous (Jackson, 1973) potassium (Tewatia, 1994), Reducing sugars were estimated by the method suggested by Paleg (1960). Total sugars were estimated by the method of Yemn and Willis (1954). Non reducing sugar was estimated by subtracting reducing sugars from total sugars. Total phenol content of samples was estimated by the method of Swain and Hills (1959). Silica percentage was determined as per AOAC (1980), by the formula given below.

$$
\text { Silica }(\%)=\frac{\text { Weight of silica }+(\text { Filter paper }- \text { Weight of Filter paper })}{\text { Weight of sample }} \times 100
$$

The per cent fruit damage and number of larvae were correlated with different biochemical traits of bitter gourd fruits to know the role of different biochemical traits in imparting resistant or susceptibility in bitter gourd fruits against melon fruit fly.

\section{Results and Discussion}

\subsection{Screening of Bitter Gourd Genotypes for Fruit Fly Infestation}

Seventy-four genotypes of bitter gourd were screened against fruit fly infestation in Agricultural Research Farm, Banaras Hindu University $\left(24^{\circ} 56^{\prime} \mathrm{N}\right.$ to $\left.82^{\circ} 12^{\prime} \mathrm{E}\right)$. On the basis of per cent fruit infestation and the average number of larvae per damaged fruit, the genotypes were categorized in to different groups i.e. (highly resistant, resistant, moderately resistant, susceptible, and highly susceptible). The genotypes of different categories showed that the lowest fruit infestation was recorded in the genotypes IC 248282, Kerala collection -1, VRBT-4 and DRAR-1, IC 68314 and these were grouped as resistant genotypes while 61 genotypes as moderately resistant, 5 genotypes as susceptible and 3 genotypes highly susceptible (Table 1). There were significant differences in per cent fruit infestation and larval density per fruit among the genotypes tested. The fruit infestation during 2009 and 2010 summer season (average of two years) ranged from $13.64 \%$ to $81.57 \%$ and larval density per fruit ranged from 2.75 to 7.88 larvae per fruit (Table 2). The correlation coefficients revealed that the larval density and bitter gourd fruit damage (\%) had significant positive relationship $(r=0.98)$ (Table 4). Dhillon et al. (2005) was also reported that the genotypes with low fruit fly infestation had low larval numbers in the fruits and there was positive correlation $(r=0.96)$ between percentage fruit infestation and number of larvae per fruit. Plant varieties/genotypes possess physiological and biochemical variations due to the environmental stress or genetic makeup, which alter the nutritional values for herbivores (Rafiq et al., 2008). The percent fruit infestation and larval density were significantly lower in resistant varieties/genotypes and higher in susceptible varieties/ genotypes of bitter gourd. 
Table 1. Grouping of bitter gourd germplasms/lines/genotypes in to different categories on the basis of per cent fruit infestation during summer season (average of two years)

\begin{tabular}{|c|c|c|c|c|c|}
\hline S. No. & $\begin{array}{l}\text { Fruit infestation } \\
(\%)\end{array}$ & $\begin{array}{l}\text { No. of } \\
\text { larvae/fruit }\end{array}$ & Reaction & $\begin{array}{l}\text { No. of } \\
\text { genotypes }\end{array}$ & Genotypes \\
\hline 1 & $1-10$ & 4.3 & Highly resistant & 0 & - \\
\hline 2 & $11-20$ & 4.9 & Resistant & 5 & $\begin{array}{l}\text { IC-248282, Kerala collection -1, VRBT-4, DRAR-1, } \\
\text { IC- } 68314\end{array}$ \\
\hline 3 & $21-50$ & 5.0 & $\begin{array}{l}\text { Moderately } \\
\text { resistant }\end{array}$ & 61 & $\begin{array}{l}\text { VRBT } 6 \text {, VRBT-7, VRBT 11, VRBT 14, VRBT } 28, \\
\text { VRBT 29, VRBT 31, VRBT 32, VRBT 35, VRBT } 37, \\
\text { VRBT 39, VRBT 41, VRBT 46, VRBT 54, VRBT } 63 \text {, } \\
\text { VRBT } 68 \text {, VRBT } 69 \text {, VRBT 71, VRBT 72, VRBT 73, } \\
\text { VRBT 75, VRBT 76, VRBT 77, VRBT 83, VRBT 85, } \\
\text { VRBT 86, VRBT 87, VRBT 90, VRBT 91, VRBT 92, } \\
\text { VRBT 94, VRBT 95, VRBT 96, VRBT 98, VRBT 99, } \\
\text { VRBT 100, VRBT 103, VRBT 107, VRBT 113, VRBT } \\
\text { 115, VRBT 128, VRBT 135, VRBT 139, VRBT145, } \\
\text { VRBT147, VRBT 178, VRBT 179, VRBT 187, VRBT } \\
\text { 188, DVBTG-1, DVBTG-2, DVBTG 5, DVBTG } 7, \\
\text { NDBT-1, Long green, Pusavishesh, Hirkani, } \\
\text { US-6201, Jhalribaramasi, BL-237, Konkan Tara }\end{array}$ \\
\hline 4 & $51-75$ & 6.1 & Susceptible & 5 & VRBT 21, VRBT 22, VRBT 38, VRBT 93, VRBT 175 \\
\hline 5 & $76-100$ & 8.1 & Highly Susceptible & 3 & Jaunpuri, Arka harit, Pusa Do Mausmi \\
\hline
\end{tabular}

Table 2. Per cent fruit infestation and larval densities of fruit fly in different genotypes of bitter gourd during summer season (Average of the 2 years 2009-2010)

\begin{tabular}{lllll}
\hline S. No. & Genotypes & Fruit infestation (\%) & No. of larvae/fruit & Reaction \\
\hline 1 & IC 248282 & $13.64(21.53)$ & $2.75(1.78)$ & Resistant \\
2 & Kerala Collection -1 & $15.68(23.17)$ & $2.85(1.81)$ & Resistant \\
3 & DRAR-1 & $18.12(25.12)$ & $3.26(1.91)$ & Resistant \\
4 & VRBT 4 & $18.76(25.49)$ & $3.40(1.95)$ & Resistant \\
5 & Konkan Tara & $24.80(29.73)$ & $4.13(2.13)$ & Moderately resistant \\
6 & Hirkani & $30.91(33.71)$ & $4.59(2.24)$ & Moderately resistant \\
7 & DVBTG-1 & $44.16(41.60)$ & $5.65(2.47)$ & Moderately resistant \\
8 & NDBT-1 & $40.11(39.07)$ & $5.23(2.37)$ & Moderately resistant \\
9 & VRBT 35 & $46.49(43.11)$ & $5.61(2.45)$ & Moderately resistant \\
10 & VRBT 93 & $55.11(48.16)$ & $6.19(2.57)$ & Susceptible \\
11 & VRBT 38 & $57.33(49.58)$ & $6.09(2.55)$ & Susceptible \\
12 & VRBT 21 & $67.01(55.32)$ & $6.77(2.69)$ & Susceptible \\
13 & VRBT 175 & $65.54(54.57)$ & $6.71(2.67)$ & Susceptible \\
14 & Jaunpuri & $76.21(61.31$ & $7.47(2.81)$ & Highly Susceptible \\
15 & Arkaharit & $78.17(62.95)$ & $7.79(2.87)$ & Highly Susceptible \\
16 & Pusa Do Mausami & $81.57(64.84)$ & $7.88(2.88)$ & Highly Susceptible \\
\hline
\end{tabular}

\subsection{Biochemical Fruit Traits and Correlation Analysis}

From each category of genotypes, 3-4 genotypes were selected for biochemical analysis (Table 3). The moisture content of the fruits of all the selected genotypes varied significantly from each other, however it varied from $86.27 \%$ (IC 248282 and DRAR-1) to $95.37 \%$ (VRBT 175). There was a significant increase in fruit fly infestation and number of larvae per fruit with an increase in moisture content of the fruits. In general, the moisture content in the resistant genotypes is lower in comparison with the highly susceptible genotypes. The moisture content had significant positive effect on the per cent fruit damage $(r=0.75)$ and number of larvae $(r=$ $0.80)$ per fruit. All the tested genotypes of bitter gourd differed significantly from each other in nitrogen, phosphorous, potassium, protein, sugars, phenol, ascorbic acid, chlorophyll, silica and ash content (Table 3 and 4). The relationship with ash content with the infestation was illustrated in Figure 1.Nitrogen, phosphorous, 
potassium and protein content ranged from $1.93 \%$ to $2.85 \%, 0.32 \%$ to $0.59 \%, 1.80 \%$ to $4.63 \%$ and $12.08 \%$ to $17.81 \%$, respectively, being minimum in Pusa Do Mausami and maximum in IC 248282. The nitrogen, phosphorous, potassium and protein content of the fruit of bitter gourd were found highest in resistant genotypes and lowest in susceptible genotypes and showed, nitrogen $(\mathrm{r}=-0.87,-0.90)$, phosphorus $(\mathrm{r}=-0.68,-0.69)$, potassium $(\mathrm{r}=-0.83,-0.88)$ and protein content $(\mathrm{r}=-0.87,-0.90)$ significant negative correlation with fruit fly infestation and number of larvae per fruit. Benepal and Hall (1967) reported that feeding of squash bug (Anasa tristis De Geer) was not affected by protein content of plants of Cucurbita pepo L. Protein as a whole may not affect the feeding of insects, whereas, particular amino acid may be responsible for imparting resistance. The non-reducing, reducing, total sugar, total phenol, silica and ash content ranged from $0.81 \%$ to $1.45 \%, 1.77 \%$ to $2.90 \%, 2.61 \%$ to $4.41 .71 \%, 93.78 \mathrm{mg}$ to $153.64 \mathrm{mg} / 100 \mathrm{~g}, 0.83 \%$ to $1.77 \%$ and $9.63 \%$ to $13.40 \%$ respectively, being minimum in Pusa Do Mausami and maximum in IC 248282. The non-reducing sugar $(\mathrm{r}=-0.82,-0.82)$, reducing sugar $(\mathrm{r}=-0.86,-0.85)$, total sugar $(\mathrm{r}=-0.87,-0.87)$, total phenol $(\mathrm{r}=-0.95,-0.92)$, silica $(\mathrm{r}=-0.93$, $-0.92)$ and ash content $(\mathrm{r}=-0.92,-0.94)$, had significant impact on the fruit damage and showed significant negative correlation with fruit fly infestation and number of larvae per fruit (Tables 3 and 4).

Table 3. Biochemical constituents of the fruits of different germplasms/lines/genotypes of bitter gourd during summer season of the years 2009-2010

\begin{tabular}{|c|c|c|c|c|c|c|c|c|c|c|c|c|c|c|c|}
\hline 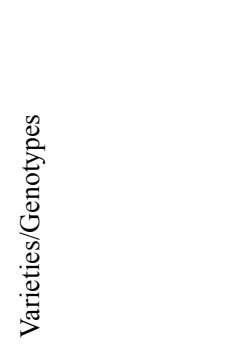 & 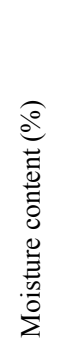 & 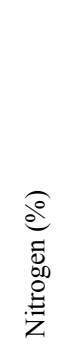 & 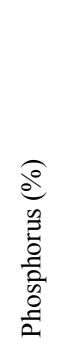 & 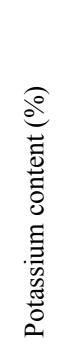 & $\begin{array}{l}\stackrel{0}{0} \\
\stackrel{0}{0} \\
\stackrel{0}{0}\end{array}$ & 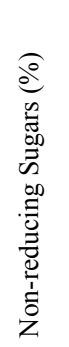 & 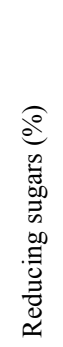 & 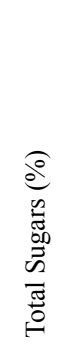 & 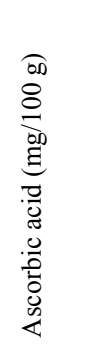 & 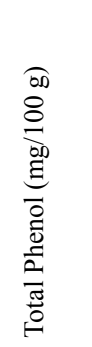 & 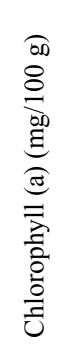 & 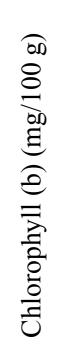 & 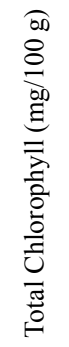 & $\frac{\widehat{d}}{\overrightarrow{0}}$ & 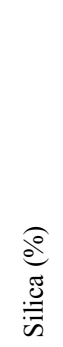 \\
\hline IC 248282 & 86.27 & 2.85 & 0.59 & 4.63 & 17.81 & 1.45 & 2.90 & 4.41 & 185.69 & 153.64 & 3.30 & 1.17 & 4.66 & 13.4 & 1.77 \\
\hline Kerala Collection -1 & 87.64 & 2.79 & 0.47 & 4.06 & 17.46 & 1.32 & 2.83 & 4.19 & 188.71 & 152.46 & 3.69 & 1.69 & 5.38 & 13.17 & 1.76 \\
\hline DRAR-1 & 86.27 & 2.77 & 0.58 & 3.81 & 17.33 & 1.30 & 2.76 & 4.09 & 174.55 & 153.34 & 3.58 & 1.75 & 5.36 & 12.70 & 1.72 \\
\hline VRBT 4 & 88.86 & 2.64 & 0.57 & 3.62 & 16.48 & 1.27 & 2.72 & 4.02 & 160.13 & 152.30 & 3.56 & 1.66 & 5.24 & 12.57 & 1.70 \\
\hline Konkan Tara & 89.27 & 2.62 & 0.52 & 3.47 & 16.38 & 1.36 & 2.70 & 4.10 & 152.22 & 152.18 & 3.64 & 1.79 & 5.88 & 12.15 & 1.66 \\
\hline Hirkani & 93.12 & 2.37 & 0.49 & 2.84 & 14.79 & 1.11 & 2.68 & 3.81 & 132.45 & 150.75 & 3.69 & 1.71 & 5.18 & 11.63 & 1.63 \\
\hline DVBTG-1 & 93.03 & 2.34 & 0.42 & 2.47 & 14.63 & 1.10 & 2.63 & 3.76 & 119.10 & 150.09 & 2.53 & 1.31 & 3.92 & 10.97 & 1.60 \\
\hline NDBT-1 & 93.76 & 2.32 & 0.44 & 2.39 & 14.48 & 1.15 & 2.61 & 3.79 & 112.97 & 146.56 & 2.89 & 1.51 & 4.44 & 10.83 & 1.50 \\
\hline VRBT 35 & 94.07 & 2.36 & 0.43 & 2.44 & 14.73 & 1.17 & 2.64 & 3.84 & 135.51 & 140.02 & 2.94 & 1.62 & 4.57 & 10.66 & 1.34 \\
\hline VRBT & 9 & 2.31 & 0.40 & 2.37 & 14.44 & 1.01 & 2 & 3.59 & 1 & 132 & 3.17 & 1.55 & 4.13 & 10.23 & 1.20 \\
\hline VRBT 38 & 94.95 & 2.33 & 0.34 & 2.26 & 14.54 & 0.95 & 2.55 & 3.53 & 119.08 & 131.37 & 3.30 & 1.44 & 4.34 & 10.34 & 1.25 \\
\hline VRBT 21 & 95.27 & 2.21 & 0.33 & 2.13 & 13.83 & 0.83 & 2.37 & 3.23 & 113.76 & 127.69 & 3.11 & 1.21 & 4.37 & 10.01 & 0.97 \\
\hline VRBT 175 & 95.37 & 1.93 & 0.32 & 2.11 & 12.08 & 0.93 & 2.26 & 3.22 & 132.86 & 120.10 & 3.42 & 1.44 & 4.90 & 10.18 & 1.15 \\
\hline Jaunpuri & 91.27 & 2.37 & 0.59 & 2.98 & 14.83 & 1.23 & 2.53 & 3.80 & 139.79 & 111.27 & 3.58 & 1.64 & 5.28 & 10.20 & 1.18 \\
\hline Arkaharit & 92.83 & 2.11 & 0.33 & 1.91 & 13.17 & 0.92 & 2.15 & 3.10 & 102.74 & 102.92 & 1.14 & 0.62 & 1.80 & 10.52 & 1.31 \\
\hline Pusa & 87 & 1.98 & 0.32 & 1.80 & 12.35 & 0.81 & 1.77 & 2.61 & 79.63 & 93.78 & 3.47 & 1.72 & 5.21 & 9.63 & 0.83 \\
\hline $\mathrm{SEM} \pm$ & 1.35 & 0.44 & 0.05 & 0.46 & 2.76 & 0.25 & 0.42 & 0.46 & 7.31 & 1.61 & 0.70 & 0.51 & 0.87 & 0.95 & 0.30 \\
\hline $\mathrm{CD}(0.05)$ & 2.74 & 0.90 & 0.11 & 0.94 & 5.62 & 0.52 & 0.85 & 0.93 & 14.89 & 3.28 & 1.43 & 1.04 & 1.77 & 1.93 & 0.60 \\
\hline
\end{tabular}


Table 4. The correlation coefficients of the fruit damage, larval density and biochemical traits of the fruits of different germplasms/lines/genotypes of bitter gourd during summer season of the years 2009-2010

\begin{tabular}{|c|c|c|c|c|c|c|c|c|c|c|c|c|c|c|c|c|c|}
\hline 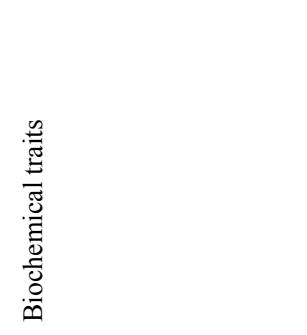 & 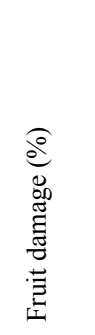 & 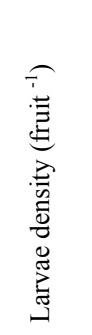 & 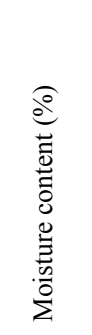 & 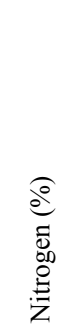 & 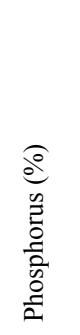 & 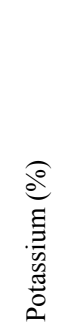 & 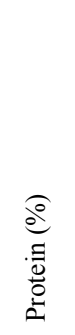 & 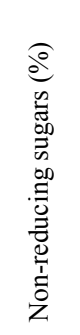 & 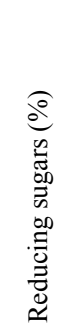 & 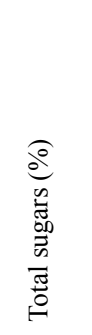 & 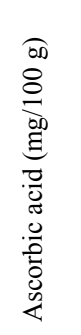 & 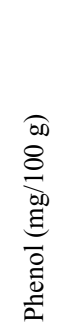 & 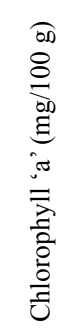 & 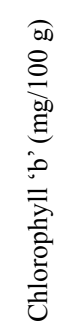 & 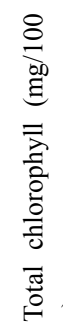 & $\frac{\partial}{\frac{\partial}{0}}$ & 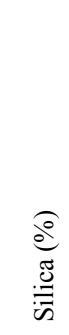 \\
\hline Fruit damage (\%) & 1.00 & & & & & & & & & & & & & & & & \\
\hline Larval density (fruit ${ }^{-1}$ ) & $0.99^{* *}$ & 1.00 & & & & & & & & & & & & & & & \\
\hline Moisture content (\%) & $0.75^{* *}$ & $0.80^{* *}$ & 1.00 & & & & & & & & & & & & & & \\
\hline Nitrogen (\%) & $-0.87^{* *}$ & $*-0.90^{* *}$ & $*-0.90 * *$ & $* 1.00$ & & & & & & & & & & & & & \\
\hline Phosphorus (\%) & $-0.68 * *$ & $*-0.69 * *$ & $*-0.82 * *$ & * 0.82 ** & 1.00 & & & & & & & & & & & & \\
\hline Potassium (\%) & $-0.83^{* *}$ & * $-0.88^{* *}$ & $*-0.94 * *$ & * $0.95^{* *}$ & $0.85^{* *}$ & $=1.00$ & & & & & & & & & & & \\
\hline Protein $(\%)$ & $-0.87^{* *}$ & $*-0.90^{* *}$ & $*-0.90 * *$ & * $1.00^{* *}$ & $0.82^{* *}$ & $0.95^{* *}$ & 1.00 & & & & & & & & & & \\
\hline Non-reducing sugars (\%) & $-0.82 * *$ & * $-0.82 * *$ & $*-0.86 * *$ & * $0.90^{* *}$ & $0.90^{* *}$ & $0.91^{* *}$ & $0.90^{* *}$ & * 1.00 & & & & & & & & & \\
\hline Reducing sugars (\%) & $-0.86^{* *}$ & * $-0.85^{* *}$ & $*-0.64 * *$ & * $0.86^{* *}$ & $0.73^{* *}$ & $0.79^{* *}$ & $0.86^{* *}$ & * $0.84 * *$ & ${ }^{k} 1.00$ & & & & & & & & \\
\hline Total sugars & $-0.87^{* *}$ & $*-0.87^{* *}$ & $*-0.77 * *$ & * $0.92 * *$ & $0.84 * *$ & $0.88^{* *}$ & $0.92 * *$ & * $0.94 * *$ & * $0.97 * *$ & ${ }^{*} 1.00$ & & & & & & & \\
\hline Ascorbic acid (mg/100 g) & $-0.79 * *$ & * $-0.83 * *$ & $*-0.82 * *$ & * $0.88^{* *}$ & $0.75^{* *}$ & $0.92^{* *}$ & $0.88^{* *}$ & * $0.85^{* *}$ & ${ }^{*} 0.83^{* *}$ & $* 0.87 * *$ & 1.00 & & & & & & \\
\hline Phenol (mg/100 g) & $-0.95 * *$ & * $-0.92 * *$ & $*-0.56^{*}$ & $0.78^{* *}$ & $0.60^{*}$ & $0.69^{* *}$ & $0.78^{* *}$ & * 0.73 ** & * $0.91 * *$ & $* 0.87 * *$ & $0.70^{* *}$ & 1.00 & & & & & \\
\hline Chlorophyll 'a'(mg/100g) & -0.38 & -0.40 & -0.29 & 0.38 & 0.44 & 0.47 & 0.38 & 0.37 & 0.33 & 0.36 & 0.46 & 0.36 & 1.00 & & & & \\
\hline Chlorophyll 'b' (mg/100 g) & -0.35 & -0.33 & -0.19 & 0.29 & 0.40 & 0.29 & 0.29 & 0.34 & 0.26 & 0.30 & 0.30 & 0.34 & $0.86^{* *}$ & 1.00 & & & \\
\hline Total chlorophyll $(\mathrm{mg} / 100 \mathrm{~g})$ & -0.43 & -0.44 & -0.37 & 0.41 & 0.51 & 0.49 & 0.41 & 0.46 & 0.33 & 0.40 & 0.45 & 0.38 & $0.96^{* *}$ & $0.90^{*}$ & 1.00 & & \\
\hline Ash (\%) & $-0.92 * *$ & * $-0.94 * *$ & $*-0.92 * *$ & * $0.92^{* *}$ & $0.73 * *$ & $0.94^{* *}$ & $0.92 * *$ & * $0.86^{* *}$ & * $0.77^{* *}$ & $* 0.84 * *$ & $0.86^{* *}$ & $0.77^{*}$ & $* 0.32$ & 0.20 & 0.37 & 1.00 & \\
\hline Silica (\%) & $-0.93 * *$ & $*-0.92 * *$ & $*-0.79 * *$ & * $0.84 * *$ & $0.71^{* *}$ & $0.81^{* *}$ & $0.84 * *$ & * $0.85^{* *}$ & $0.85^{* *}$ & * $0.88^{* *}$ & $0.75^{* *}$ & $0.86^{* *}$ & $* 0.16$ & 0.16 & 0.23 & $0.91 * *$ & * 1.00 \\
\hline
\end{tabular}

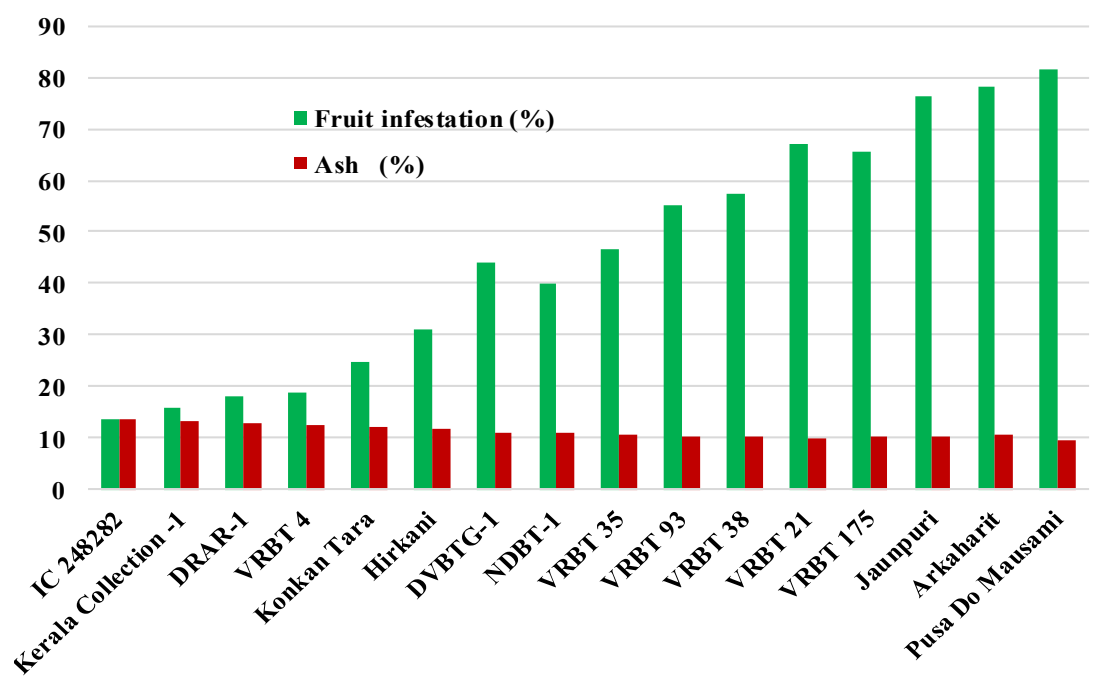

Figure 1. Relationship between ash content and fruit infestation percentage

The total sugars, reducing sugars and non - reducing sugars were higher in resistant genotypes as compare to susceptible genotypes. However, in an earlier study, Sharma and Hall (1971) reported positive correlation between spotted cucumber beetle (Diabrotica undecimpunctata. Howardi) feeding and total sugars concentration of various cucurbitaceous crops. Ingoley et al. (2005) they reported that the cucumber fruits of susceptible and highly susceptible genotypes revealed higher amount of total sugar as compared to moderately resistance 
genotypes. In earlier study, Chelliah and Sambandam (1971) also reported that the resistance to melon fruit fly (D. cucurbitae) in Cucumis callosus appeared to be associated with high silica content of the fruits. It is concluded that higher amounts of tannin, flavonol, total phenol and silica contents of fruits of resistance genotypes may be responsible for imparting resistance against melon fruit fly in bitter gourd. The bitter gourd genotypes differed significantly from each other in ascorbic acid content. The ascorbic acid content differed from $79.63 \mathrm{mg} / 100 \mathrm{~g}$ to $188.71 \mathrm{mg} / 100 \mathrm{~g}$ of fresh weight. The highest ascorbic acid content was recorded in the genotype Kerala collection $-1(188.71 \mathrm{mg} / 100 \mathrm{~g})$, and lowest was recorded in the genotype Pusa Do Mausami $(79.63 \mathrm{mg} / 100 \mathrm{~g})$. The ascorbic acid also had significant impact on the fruit damage and showed significant negative correlation with fruit fly infestation $(\mathrm{r}=-0.79)$ and number of larvae per fruit $(\mathrm{r}=-0.83)$. Chelliah (1970) suggested that perception of chemical stimuli was well developed in B. cucurbitae. Melon fruit fly infestation and larval density per fruit increased with increase in moisture level; while ascorbic acid, reducing, non-reducing and total sugars, nitrogen, protein, phosphorous and potassium contents were greater in resistant genotypes when compared with susceptible ones. Similar findings have also been reported by Tewatia et al. (1998). The significant difference was observed for chlorophyll 'a', 'b', and total chlorophyll content in the fruits of various genotypes of bitter gourd and it was ranged from 1.14 to $3.69 \mathrm{mg} / 100 \mathrm{~g}, 0.62$ to $1.79 \mathrm{mg} / 100 \mathrm{~g}$ and 1.80 to 5.88 $\mathrm{mg} / 100 \mathrm{~g}$ fresh weight respectively. The chlorophyll content was recorded highest in the fruits of genotype Konkantara $(5.88 \mathrm{mg} / 100 \mathrm{~g})$, and lowest in the genotype Arkaharit. The chlorophyll ' $\mathrm{a}$ ' $(\mathrm{r}=-0.38,-0.40)$, chlorophyll ' $\mathrm{b}$ ' $(\mathrm{r}=-0.35,-0.33)$ and total chlorophyll $(\mathrm{r}=-0.43,-0.44)$ had non-significant negative effect on the fruit damage (\%) by fruit fly and number of larvae per fruit. The allelochemical compounds of fruit were significantly different among the tested muskmelon varieties/genotypes. In brinjal and okra crop, the biochemical characters such as total sugar and crude protein were positively correlated with fruit borer infestation, whereas total phenols were negatively correlated (Jat \& Pareek, 2003; Sharma \& Singh, 2010). Very little information is available on correlation of the biochemical traits. Biochemical characters such as total sugar and crude protein were positively correlated whereas total phenols were negatively correlated with fruit borer nfestation (Haldhar et al., 2013). Phenolic heteropolymers play a central role in plant defense against insects and pathogens (Barakat et al., 2010). Phenols also play an important role in cyclic reduction of reactive oxygen species such as superoxide anion and hydroxide radicals, $\mathrm{H}_{2} \mathrm{O}_{2}$, and singlet oxygen, which in turn activate a cascade of reactions leading to the activation of defensive enzymes (Maffei et al., 2007).

\section{Conclusion}

The silica and ash content were playing an important role in pest resistance. It is very well documented silica has clear prophylactic effect with wide range of insect feeding guilds, including lepidopteran borers, folivores, phloem feeding insects and other plant feeders. Hence we suggest that reduction in fruit fly infestations on resistant varieties/genotypes could be due to prophylactic effects of Silica and ash content and biochemical/Allelochemical traits. Certain biochemical traits (e.g., Total sugar, phenols and ascorbic acid, described related to resistance of bitter gourd against $B$. cucurbitae and, therefore, can be used as marker traits in plant breeding programs to select resistant varieties/genotypes.

\section{References}

Allwood, A. J., Chinajariyawong, A., Drew, R. A. I., Hamacek, E. L., Hancock, D. L., Hengsawad, C., ... Vijasegaran, S. (1999). Host plant records for fruit flies (Diptera: Tephritidae) in Southeast Asia. The Raffles Bulletin of Zoology, 7, 1-92.

Anonymous. (1992). Report on infrastructure for export of agricultural commodities and processed food (p. 44). Govt. of India, Planning commission (Agriculture Division), Yojana Bhawan, New Delhi.

AOAC. (1960). Official methods of Analysis, Association of Agricultural Chemists. Washington, D. C.

AOAC. (1980). Official methods of Analysis, Association of Agricultural Chemists. Washington, D. C.

AOAC. (1985). Official methods of Analysis, Association of Agricultural Chemists. Washington, D. C.

Aslam, M., \& Stockley, I. H. (1979). Interaction between curry ingredient (Karela) and drug (chlorpropamide). Lancet, 1(8116), 607. https://doi.org/10.1016/S0140-6736(79)91028-6

Awasthi, C. P., \& Jaiswal, R. C. (1986). Biochemical composition and nutritional quality of fruits of bitter gourd grown in Uttar Pradesh. Progressive Horticulture, 18, 265-269.

Baldwa, V. S., Bhandari, C. M., Pangaria, A., \& Goyal, R. K. (1977). Chemical trial in patients with diabetes mellitus of an insulin like compounds obtained from plant source. Upsala Journal of Medical Sciences, 82, 39-41. https://doi.org/10.3109/03009737709179057 
Barakat, A., Bagniewska-Zadworna, A., Frost, C. J., \& Carlson, J. E. (2010). Phylogeny and expression profiling of CAD and CAD-like genes in hybrid Populus $(P$. deltoids $\times P$. nigra $)$ : Evidence from herbivore damage for sub functionalization and functional divergence. BMC Plant Biology, 10, 1-11. https://oi.org/10.1186/ 1471-2229-10-100

Benepal, P. S., \& Hall, C. V. (1967). The influence of mineral nutrition of varieties of Cucurbita pepo L. on the feeding response of squash bug Anasa tristis De Geer. Proceedings of the American Society of Horticultural Science, 90, 304-312.

Chelliah, S. (1970). Host influence on the development of melon fly, Dacus cucurbitae Coquillett. Indian Journal of Entomology, 32, 381-383.

Chelliah, S., \& Sambandam, C. N. (1971). Role of certain mechanical factors in Cucumis callosus (Rottl.) Cogn. in imparting resistance to Dacus cucurbitae. Auara, 3, 48-53.

Chinajariyawong, A., Kritsaneepaiboon, S., \& Drew, R. A. I. (2003). Efficacy of protein bait sprays in controlling fruit flies (Diptera: Tephritidae) infesting angled luffa and bitter gourd in Thailand. The Raffles Bulletin of Zoology, 51(1), 7-15.

Dhillon, M. K., Singh, R., Naresh, J. S., \& Sharma, N. K. (2005). Influence of physio-chemical traits of bitter gourd, Momordica charentia L. on larval density and resistance to melon fruit fly, Bactrocera cucurbitae (Coquillet). Journal of Applied Entomology, 129(7), 395-399. https://doi.org/10.1111/j.1439-0418.2005. 00911.x

El-Batran, S. A. E. S., El-Gengaihi, S. E., \& El-Shabrawya, O. A. (2006). Some toxicological studies of Momordica charantia L. on albino rats in normal and alloxan diabetic rats. Journal of Ethnopharmacology, 108, 236-242. https://doi.org/10.1016/j.jep.2006.05.015

Haldhar, S. M., Bhargava, R., Choudhary, B. R., Pal, G., \& Kumar, S. (2013). Allelochemical resistance traits of muskmelon (Cucumis melo) against the fruit fly (Bactrocera cucurbitae) in a hot arid region of India. Phytoparasitica, 41,473-481. https://doi.org/10.1007/s12600-013-0325-X

Ingoley, P., Mehta, P. K., Chauhan, Y. S., Singh, N., \& Awasthi, C. P. (2005). Evaluation of cucumber genotype for resistance to fruit fly under mid hill condition of Himachal Pradesh. Journal of Entomological Research, 29(1), 57-60.

Jackson, M. L. (1973). Vandomolybdate phosphoric yellow colour method for determination of phosphorus. Soil Chemical Analysis. Prentice Hall of India, New Delhi.

Jat, K. L., \& Pareek, B. L. (2003). Biophysical and biochemical factors of resistance in brinjal against Leucinodes orbonalis (Guen). Indian Journal of Entomology, 65, 252-258.

Kapoor, V. C. (1993). Indian fruit flies. Oxford and IBH Publications (p. 228). New Delhi, India.

Kedar, P., \& Chakraborti, C. H. (1982). Effect of bitter gourd and glibenclamide in streptozotocin induced diabetes Mellitus. Indian Journal of Experimental Biology, 28, 232-235.

Maffei, M. E., Mithöfer, A., \& Boland, W. (2007). Insects feeding on plants: Rapid signals and responses preceding the induction of phytochemical release. Phytochemistry, 68, 2946-2959. https://doi.org/10.1016/ j.phytochem.2007.07.016

Mahlberg, P., \& Venketeswaran, G. S. (1966). Pigment analysis of normal and proliferated genetical strains of Nicotiana under cultural conditions. Botanical Gazette, 127, 114-9. https://doi.org/10.1086/336351

Maxwell, P. G., \& Jennings, P. R. (Eds.). (1980). Breeding plants resistance to insects (p. 683). John Wiley and Sons, New York, USA.

Nath, P. (1966). Varietal resistance of gourds to the fruit flies. Indian Journal of Horticulture, 23(2), 69-79.

Nath, P., \& Bhushan, S. (2006). Screening of cucurbit crops against fruit fly. Annals of Plant Protection Science, $14,472-473$.

Paleg, L. G. (1960). Physiological effects of gibberellic acid on carbohydrate metabolism and amylase activity of barley endosperm. Plant Physiology, 35, 293-299. https://doi.org/10.1104/pp.35.3.293

Panda, N., \& Khush, G. S. (1995). Host plant resistance to insects (p. 435). Wallingford, UK: CAB International. 
Panday, A. K., Nath, P., \& Rai, A. B. (2008). Efficacy of some eco-friendly insecticides, poisons baits and their combinations against bitter gourd infestation by melon fruit fly (Bactrocera cucurbitae Coquillet). Vegetable Science, 35(2), 152-155.

Panday, A. K., Nath, P., Rai, A. B., \& Kumar, A. (2009). Screening of some bitter gourd varieties/germplasms on the basis of some biological and biometrical parameters of melon fruit fly (Bactrocera cucurbitae Coquillet) Vegetable Science, 36(Suppl. 3), 399-400.

Pareek, B. L., \& Kavadia, V. S. (1995). Screening of muskmelon varieties against melon fruit fly, Dacus cucurbitae Coquillett under field conditions. Indian Journal of Entomology, 57, 417-420.

Rafiq, M., Ghaffar, A., \& Arshad, M. (2008). Population dynamics of whitefly (Bemisia tabaci) on cultivated crop hosts and their role in regulating its carry-over to cotton. International Journal of Agricultural Biology, $9,68-70$.

Ronald, J., Prokopy, N. W., Miller, J. C., Piñero, L. O., Nancy, C., Hannah, R., \& Roger, I. V. (2004). How effective is gf-120 fruit fly bait spray applied to border area sorghum plants for control of melon flies (Diptera: Tephritidae)? Florida Entomologist, 87(3), 354-360. https://doi.org/10.1653/0015-4040(2004)087 [0354:HEIGFF]2.0.CO;2

Sarfaraz, A., Ansari, S. H., \& Porchezhian, E. (2002). Antifungal activity of alcoholic extracts of Ziziphus vulgaris and Acacia concinna. Hamdard Medicus (pp. 14-15, pp. 42-45). Bait Al-Hikmah, Karachi, Pakistan.

Sharma, B. N., \& Singh, S. (2010). Biophysical and biochemical factors of resistance in okra against shoot and fruit borer. Indian Journal of Entomology, 72, 212-216.

Sharma, G. C., \& Hall, C. V. (1971). Influence of cucurbitacins, sugars and fatty acids on cucurbit susceptibility to spotted cucumber beetle. American Society of Horticultural Science, 96, 675-680.

Swain, T., \& Hills, H. (1959). Phenolic constituents of Prunus domestica. Quantitative analysis of phenolic constituents. Journal of the Science of Food and Agriculture, 10, 63-68. https://doi.org/10.1002/jsfa.27 40100110

Tewatia, A. S. (1994). Resistance studies in bitter gourd against melon fruit fly (p. 73, Ph.D. thesis). Chaudhary Charan Singh Haryana Agriculture University, Hisar, India.

Tewatia, A. S., Dhankhar, B. S., \& Singh, R. (1998). Evaluation of bitter gourd (Momordica charentia L.) cultivars for resistance to melon fruit fly (Bactrocera cucurbitae Coq.). Haryana Journal of Horticultural Science, 27(4), 266-271.

Yemm, E. W., \& Willis, A. J. (1954). The estimation of carbohydrate in the plant extract by anthrone reagent. Journal of Biochemistry, 57, 508-514. https://doi.org/10.1042/bj0570508

\section{Copyrights}

Copyright for this article is retained by the author(s), with first publication rights granted to the journal.

This is an open-access article distributed under the terms and conditions of the Creative Commons Attribution license (http://creativecommons.org/licenses/by/4.0/). 